CATALLAXY

Volume 1 Issue 1 December 2016

e-ISSN 2544-090X

ऽwww.catallaxy.pl

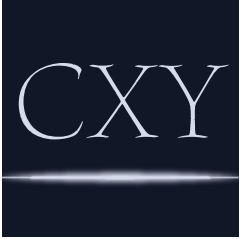

Oryginalny artykut naukowy

otrzymano: 05.12.2016 / zaakceptowano: 28.12.2016 / opublikowano online: 31.12 .2016

()ㅜㅇㅛ

Bernacka, P. (2016). Makroekonomiczne determinanty bezrobocia na przykładzie Polski i Stanów Zjednoczonych w latach 2000-2016. Catallaxy, 1(1): 31-38. doi:10.24136/cxyv 1i1.3.

\title{
Makroekonomiczne determinanty bezrobocia na przykładzie Polski i Stanów Zjednoczonych w latach 2000-2016
}

\author{
PAULINA BERNACKA \\ Wydziat Nauk Ekonomicznych i Zarządzania, Uniwersytet Mikotaja Kopernika w Toruniu, ul. Gagarina 13a, \\ 87-100 Toruń, Polska \\ øpaulinabernacka1@wp.pl
}

\begin{abstract}
Abstrakt
Motywacja: Uzasadnieniem wyboru tematu jest duże znaczenie zjawiska długookresowego bezrobocia dla rozwoju gospodarczego oraz metod profilowania bezrobotnych, które mają zapobiegać temu zjawisku.

Cel: Celem artykułu był wybór makroekonomicznych determinant długookresowego bezrobocia w Polsce i Stanach Zjednoczonych. Analiza koncentrowała się także na omówieniu możliwości zwalczania długookresowego bezrobocia dzięki profilowaniu bezrobotnych oraz dotychczasowych rezultatów tej metody w Polsce.

Wyniki: W sposób statystycznie istotny na stopę bezrobocia oddziałują następujące zmienne makroekonomiczne: stopa bezrobocia z poprzedniego kwartału, realna stopa wzrostu PKB, stopa inflacji, stopa wzrostu udziału eksportu w PKB oraz inwestycje. W większości przypadków wpływ ten okazał się być zgodny z teorią ekonomii. W Polsce stopa bezrobocia najsilniej reaguje na zmiany PKB w przeciwnym kierunku. Można zatem oczekiwać, że stymulowanie wzrostu gospodarczego lub podejmowanie działań wspierających go w długim okresie, powinno przełożyć się na spadek stopy bezrobocia w Polsce. W Stanach Zjednoczonych na stopę bezrobocia w sposób znaczący oddziałuje zarówno stopa wzrostu udziału eksportu w PKB, jak i inwestycje.
\end{abstract}

Stowa kluczowe: bezrobocie; Polska; Stany Zjednoczone; determinanty bezrobocia; profilowanie bezrobotnych JEL: J64; E23; 13

\section{Wprowadzenie}

Bezrobocie nie jest pojęciem jednoznacznym. Znajomość jego wielowymiarowości wydaje się być kluczowa dla wdrażania odpowiednich narzędzi zwalczania tego niekorzystnego zjawiska. Jego występowanie oznacza obecność na rynku pracy wolnego zasobu siły roboczej, który nie znajduje zatrudnienia. Pojęcie bezrobocia rozpatrywać można zarówno posługując się przedmiotowym, jak i podmiotowym podejściem do tego problemu.
W ujęciu przedmiotowym bezrobocie jest wynikiem braku równowagi między podażą siły roboczej (tzw. zasobów ludzkich) a popytem na pracę (możliwościami zatrudnieniowymi w gospodarce) i stanowi niezrealizowaną podaż pracy. W tym ujęciu bezrobocie stanowi istotny problem ekonomiczny. Bezrobocie $\mathrm{w}$ ujęciu podmiotowym jest kwestią społeczną, stanem przymusowej bezczynności zawodowej osób, które są zdolne do pracy i zgłaszają gotowość, aby ją podjąć. Podstawą 
egzystencji tych osób jest dochód $z$ pracy (Buchwald, 2009).

Długotrwałe bezrobocie oznacza, że system gospodarczy nie realizuje jednej z podstawowych potrzeb społeczeństwa, jaką jest potrzeba pracy. Niewypełnianie przez państwo fundamentalnych funkcji, związanych $z$ zatrudnieniem, doprowadza do strat na gruncie ekonomicznym, społecznym oraz psychologicznym. Generuje to także szkody po stronie samych bezrobotnych $\mathrm{w}$ postaci: obniżenia poziomu życia osób bezrobotnych oraz ich rodzin, emigracji młodych i wykształconych osób, frustracji, zarówno poszczególnych jednostek, jak i nawet całych grup społecznych, czy pojawiającego się zjawiska patologii społecznej (Jaśkiewicz, 2016). Występowanie długotrwałej formy bezrobocia niesie za sobą ogromne straty na gruncie makroekonomicznym. Pośród makroekonomicznych skutków długotrwałego bezrobocia należy wymienić: liczne wydatki publiczne, spadek PKB, rozwijanie się tzw. szarej strefy oraz różnice $\mathrm{w}$ rozwoju poszczególnych regionów (Dolny i in., 2014).

Bezrobocie długookresowe stanowi jeden $z$ typów bezrobocia chronicznego. Kryterium wyodrębnienia stanowi $\mathrm{w}$ tym przypadku długość okresu, podczas którego osoba bezrobotna poszukuje pracy. Zaznaczyć należy, że nie jest to jednak precyzyjne kryterium, ponieważ nie odsyła ono do czasu, który upłynął od daty ostatniego zarejestrowania bezrobotnego lub pozostawania bez zatrudnienia w konkretnym okresie chronologicznym. W tej kwestii wyróżnić można dwa podejścia. Zgodnie $z$ pierwszym $z$ nich, za bezrobotnego długotrwale uważana jest osoba, która dłużej niż 12 miesięcy bez przerwy oraz bez skutku poszukuje zatrudnienia. Według podejścia drugiego, bezrobotnym długotrwale jest osoba, która zarejestrowana była w poszczególnych bazach bezrobotnych w ciągu pewnej liczby lat. Wynika ono $z$ Ustawy o promocji zatrudnienia i instytucjach rynku pracy (2004), zgodnie z którą długotrwale bezrobotnym jest osoba pozostająca $\mathrm{w}$ rejestrze powiatowego urzędu pracy przez 12 miesięcy w ciągu ostatnich dwóch lat (wyłączając przy tym okresy odbywania oraz przygotowania zawodowego dorosłych).

Celem artykułu jest analiza czynników makroekonomicznych wpływających na poziom bezrobocia w Polsce i Stanach Zjednoczonych oraz przedstawienie narzędzia, jakim jest profilowanie bezrobotnych, jako skutecznego sposobu oddziaływania na poprawę sytuacji na rynku pracy.

W Sekcji 2. dokonano przeglądu literatury dotyczącej konsekwencji bezrobocia, zdefiniowano również pojęcie i znaczenie profilowania bezrobotnych. W Sekcji 3. nakreślono metodologię badania i źródła danych. Rezultaty badania przedstawiono w Sekcji 4., natomiast główne konkluzje w Sekcji 5.

\section{Przegląd literatury oraz pojęcie profilowania bezrobotnych}

Podjęta tematyka bezrobocia to kwestia szczególnie ważna, ponieważ bezrobocie powoduje nie tylko brak wykorzystania trudno odnawialnego zasobu ludzkiej pracy, ale wraz z poprawiającą się sytuacją na rynku pracy można oczekiwać polepszenia jakości życia (Ręklewski i Ryczkowski, 2016).

Zjawisko bezrobocia może przyczynić się do wzrostu społecznych kosztów zatrudnienia po stronie państwa, powstania strat finansowych (np. wypłata zasiłków) lub utraconych korzyści (np. w postaci podatków). Co więcej, osoby bezrobotne są narażone na ubytek kapitału ludzkiego w czasie pozostawania bez pracy.

Profilowanie bezrobotnych (unemployed profiling) jest instrumentem polityki rynku pracy kierowanym do grup problemowych, stosowanym w celu przeciwdziałania długookresowemu bezrobociu. Stosunkowo nowa, stworzona w Stanach Zjednoczonych, koncepcja polega na zidentyfikowaniu osób, które są zagrożone tym typem bezrobocia. W przeciwieństwie do wykorzystywanych wcześniej narzędzi, które sprowadzały się głównie do redukcji istniejącego już zasobu osób bezrobotnych długookresowo, profilowanie polega na zmniejszeniu napływu nowych osób do 
długotrwałego bezrobocia. Dzieje się to przy pomocy wczesnego identyfikowania osób narażonych na długotrwałe pozostawanie bez pracy, a następnie doboru i zastosowania w stosunku do tych osób skutecznych form pomocy (Wiśniewski, 2012).

Profilowanie to swoisty podział osób pozostających bez pracy ze względu na kryterium zagrożenia długotrwałym bezrobociem (Wojdyło-Preisner, 2009). Profilowanie osób zagrożonych bezrobociem długotrwałym jest szczególnie istotnym elementem polityki rynku pracy. Osoby te, w wyniku nieudanych poszukiwań, przejawiają tendencję to zaprzestawania działań w tym zakresie. Skutkiem powyższego mogą one przybrać bierną postawę zawodową i bezrobocie może stać się dla nich stylem na życia (Wojdyło-Preisner, 2013).

Wczesne rozpoznanie jednostek zagrożonych długookresowym pozostawaniem bez pracy zapobiega zaistnieniu u nich negatywnych efektów, związanych $z$ bezrobociem oraz wspiera je $w$ powrocie do zatrudnienia. Jednocześnie działania takie stanowią istotny warunek dla skuteczności przedsięwzięć realizowanych $w$ ramach aktywnej polityki rynku pracy. Należy jednak mieć na uwadze, że zastosowanie tego narzędzia wiąże się z dokładnym adresowaniem poszczególnych zadań oraz ich przebiegu w stosunku do zmiennego popytu na pracę. Postępowanie zgodnie $z$ powyższymi warunkami, umożliwi zmniejszenie tzw. jałowych wydatków oraz przyczyni się do skuteczności podejmowanych działań (Wojdyło-Preisner, 2013).

Podkreślić należy, że narzędzie to stanowi również element europejskiej polityki rynku pracy, wyznaczanej przez Europejska Strategie Zatrudnienia z 2001 roku. Jeden z filarów strategii stanowi o wzroście zatrudnienia, którego elementem jest zasada wczesnej interwencji na rynku pracy. Profilowanie bezrobotnych jest zatem skutkiem ewolucji założeń implementowanych ze strategii (Wojdyło-Preisner, 2013, ss. 33-62).

Zaznaczyć warto, że o ile w Stanach Zjednoczonych zjawisko długotrwałego bezrobocia ma znacznie mniejszy zakres niż w Europie, dokładność przewidywania może okazać się mniej trafna podczas pierwszych miesięcy bycia osobą bezrobotną. Dlatego też, w celu podniesienia efektywności, zasadnym jest zastosowanie profilowania w późniejszym okresie trwania bezrobocia, co umożliwia także uniknięcie tzw. efektu jałowego biegu (Wojdyło-Preisner, 2009, s. 56).

Celem wprowadzonych w 2014 roku zmian do Ustawy o promocji zatrudnienia i instytucjach rynku pracy (2004), czy też do innych, uchwalonych przez Sejm ustaw, było zobligowanie pracowników powiatowych urzędów pracy do kierowania i wykorzystywania optymalnych form pomocy, dostosowanych do potrzeb konkretnych bezrobotnych, przy równoczesnym posiadaniu ograniczonych zasobów finansowych. Dużą pomoc $w$ tym procesie stanowi tzw. ocena potencjału zatrudnieniowego konkretnego bezrobotnego, która w znacznym stopniu ułatwia dobranie adekwatnych form pomocy (MPiPS, 2014).

\section{Metodologia}

Czerpiąc $z$ doświadczeń zarówno państw Unii Europejskiej, jak i OECD dotyczących profilowania osób bezrobotnych wnioskuje się, że funkcjonujące rozwiązania opierają się $\mathrm{w}$ dużej mierze na ekonometrycznym modelowaniu. Warto również zaznaczyć, że nie utworzono jeszcze uniwersalnego, jednolitego, wzorowego modelu profilowania, możliwego do wprowadzenia we wszystkich państwach wykorzystujących tę metodę.

$\mathrm{W}$ analizie wykorzystano kwartalne szeregi czasowe dla Polski i Stanów Zjednoczonych obejmujące okres od pierwszego kwartału 2000 roku do drugiego kwartału 2016 roku. Daje to ponad sześćdziesiąt obserwacji, co stanowi dużą próbę. Źródłem danych jest Eurostat (2017) oraz Główny Urząd Statystyczny (GUS, 2017). Przyjęto założenie, że na stopę bezrobocia w okresie obecnym wpływają pozostałe zmienne makroekonomiczne, maksymalnie opóźnione o cztery kwartały. Przyjęty rząd opóźnień mieści się w zalecanej, $10 \%$ długości próby. 
Dobór zmiennych do modelu ekonometrycznego przeprowadzono wykorzystując metodę selekcji a posteriori, polegającą na tym, że do modelu przyjęto zmienne będące bezpośrednimi przyczynami stopy bezrobocia lub, wobec braku możliwości określenia przyczyn, zmienne najsilniej skorelowane ze stopą bezrobocia (Kośko i Osińska, 2007b, s. 25). Przyjęto, że w pierwszej kolejności eliminowane zostały zmienne $z$ najwyższą wartością $p$ (poziomu istotności), przy dopuszczalnym jego poziomie wynoszącym 0,1.

Postać modelu szacowanego dla Polski i Stanów Zjednoczonych dana jest wzorem (1):

$$
\begin{aligned}
& U_{t}=\alpha_{0}+\sum_{k=1}^{4} \alpha_{1 k} U_{t-k}+ \\
& +\sum_{k=0}^{4} \alpha_{2 k} P K B_{t-k}+\sum_{k=0}^{4} \alpha_{3 k} C P I_{t-k}+ \\
& +\sum_{k=0}^{4} \alpha_{4 k} E_{t-k}+\sum_{k=0}^{4} \alpha_{5 k} I_{t-k}+\varepsilon_{t}
\end{aligned}
$$

gdzie:

$U_{t}$-stopa bezrobocia (w\%);

$P K B_{t}$ - stopa wzrostu realnego $\mathrm{PKB}$ w stosunku do analogicznego kwartału z ubiegłego roku (w \%);

$C P I_{t}$ - stopa inflacji mierzona wskaźnikiem CPI (Consumer Price Index) $\mathrm{w}$ stosunku do analogicznego kwartału $z$ ubiegłego roku (w \%);

$E X_{t}$ - stopa wzrostu eksportu w stosunku do analogicznego kwartału $z$ ubiegłego roku (w \% PKB);

$I_{t}$ - bezpośrednie inwestycje zagraniczne w przypadku Polski (w\% PKB), stopa wzrostu wskaźnika RGPDI (Real Gross Private Domestic Investment) stosunku do analogicznego kwartału $z$ ubiegłego roku w przypadku USA $(\mathrm{w} \%)$;

$\varepsilon_{t}-$ składnik losowy;

$\alpha$ - parametry strukturalne modelu;

$t$ - operator czasu;

$k$ - rząd opóźnień.

Model (1) estymowano metodą najmniejszych kwadratów (KMNK). Jej istotą jest takie wyznaczenie ocen nieznanych parametrów strukturalnych danego modelu, aby różnice między wartościami zaobserwowanymi, a wartościami teoretycznymi, wyznaczonymi $z$ modelu, były jak najmniejsze. Funkcja kryterium minimalizacji sumy kwadratów reszt dana jest wzorem (2) (Kośko i Osińska, 2007a, ss. 45-47):

$$
\min \sum_{i=1}^{n} r^{2}
$$

gdzie:

$r$ - reszty $z$ danego modelu.

\section{Wyniki badania}

Wyniki estymacji modelu (1) dla Polski i Stanów Zjednoczonych przedstawiono odpowiednio $w$ tabeli 1 . i tabeli 2.

$\mathrm{Na}$ podstawie przeprowadzonej analizy można stwierdzić, że bezrobocie w Polsce jest procesem autoregresyjnym rzędu pierwszego. Bezrobocie $\mathrm{w}$ poprzednim kwartale $\mathrm{w}$ bardzo wysokim stopniu wpływa na bezrobocie w bieżącym kwartale. Wzrost stopy wzrostu PKB o 1 p.p. wpływa na zmniejszenie stopy bezrobocia aż o 8 p.p., jednakże z opóźnieniem jednego roku. Analogicznie, spadek stopy wzrostu PKB o 1 p.p. zwiększa po roku stopę bezrobocia o 8 p.p.

W modelu wykazano również, że wzrost stopy inflacji o 1 p.p. powoduje wzrost stopy bezrobocia o 16 p.p. z półrocznym opóźnieniem. Wynik ten nie jest zgodny $z$ krótkookresową krzywą Phillipsa. W modelu nie uwzględniono poziomu stóp procentowych banku centralnego. W związku z tym, uzyskany $\mathrm{w}$ modelu wynik może być prawdopodobnie wyjaśniony tym, że wzrost stopy inflacji przyczynia się do konieczności podniesienia stóp procentowych przez bank centralny, aby osiągnąć cel inflacyjny. W rezultacie jednak wyższe stopy procentowe prowadzą do osłabienia zagregowanego popytu i wzrostu stopy bezrobocia.

Podobnie, jak w przypadku stopy wzrostu $\mathrm{PKB}$, na stopę bezrobocia oddziałują w Polsce udział eksportu oraz udział inwestycji w PKB. 
Wzrost udziału eksportu o 1 p.p. zmniejsza stopę bezrobocia o 3 p.p. z opóźnieniem jednego kwartału. Analogicznie, spadek udziału eksportu o 1 p.p. po jednym kwartale zwiększa stopę bezrobocia o wspomniane 3 p.p. $Z$ kolei skumulowany wzrost (spadek) udziału inwestycji w gospodarce o 1 p.p. powoduje $\mathrm{w}$ długim okresie spadek (wzrost) stopy bezrobocia o 2,5 p.p. Wyniki te należy uznać za zgodne $z$ teorią ekonomii.

W modelu dla Stanów Zjednoczonych również występuje autoregresja stopy bezrobocia pierwszego rzędu. Stopa bezrobocia w Stanach Zjednoczonych bardzo silnie zależy od stopy bezrobocia w poprzednim kwartale.

Pewnym zaskoczeniem jest niejednoznaczny wpływ stóp wzrostu $\mathrm{PKB}$ na stope bezrobocia w Stanach Zjednoczonych. Prawdopodobnie może to wynikać $z$ bardzo silnych zaburzeń na rynkach finansowych, spowodowanych tzw. kryzysem subprime, który mógł zaburzyć pewne relacje $\mathrm{w}$ gospodarce doprowadzając do silnego osłabienia działalności gospodarczej. Pierwsze oznaki osłabienia koniunktury pojawiły się w Stanach Zjednoczonych już w 2006 roku, czyli mniej więcej $\mathrm{w}$ połowie analizowanego okresu.

Podobnie, jak w przypadku Polski, wzrost stopy inflacji powoduje wzrost stopy bezrobocia, co może być związane $z$ antyinflacyjną polityką Rezerwy Federalnej i podnoszeniem stóp procentowych $\mathrm{w}$ celu złagodzenia presji inflacyjnej.

Wzrost udziału eksportu w PKB o 1 p.p. obniża stopę bezrobocia o 1,5 p.p. w następnym kwartale. Analogicznie, spadek udziału eksportu o 1 p.p. podwyższa stopę bezrobocia o 1,5 p.p. w następnym kwartale.

$\mathrm{Na}$ stopę bezrobocia bardzo silnie wpływa udział inwestycji w Stanach Zjednoczonych. Wzrost (spadek) udziału inwestycji o 1 p.p. przekłada się na spadek (wzrost) stopy bezrobocia o 4 p.p. w długim okresie.

\section{Zakończenie}

W artykule wykazano, że ryzyko bezrobocia zależy od wielu różnych makroekonomicznych czynników, które z różną siłą determinują prawdopodobieństwo bycia osobą bezrobotną lub długotrwale bezrobotną. W szczególności oznacza to, że profilowanie bezrobotnych jest zadaniem bardzo ważnym, a wręcz niezbędnym do wyspecyfikowania osób lub grup osób szczególnie narażonych na niebezpieczeństwo braku pracy, zwłaszcza długotrwałego.

Przeprowadzona analiza ekonometryczna dla Polski i Stanów Zjednoczonych wykazała, że stopa bezrobocia $\mathrm{w}$ poprzednim kwartale wpływa istotnie na stopą bezrobocia w okresie bieżącym. Rezultat ten może potwierdzać występowanie zjawiska histerezy. Zgodnie z wynikami analizy, wzrost stopy bezrobocia w danym kwartale może mieć długoterminowe, niekorzystne skutki dla sytuacji gospodarczej w państwie.

Ponadto wykazano, że w sposób statystycznie istotny na stopę bezrobocia oddziałują następujące zmienne makroekonomiczne: stopa bezrobocia $z$ poprzedniego kwartału, realna stopa wzrostu PKB, stopa inflacji, stopa wzrostu udziału eksportu w PKB oraz inwestycje. W większości przypadków wpływ ten okazal się być zgodny z teorią ekonomii. Stopa bezrobocia $w$ Polsce najsilniej reaguje na zmiany $\mathrm{PKB} w$ przeciwnym kierunku. Można oczekiwać, że stymulowanie wzrostu gospodarczego lub podejmowanie działań wspierających go w długim okresie, powinno przełożyć się na spadek stopy bezrobocia w Polsce. Z kolei w Stanach Zjednoczonych na stopę bezrobocia w sposób znaczący oddziałują zarówno stopa wzrostu udziału eksportu w PKB, jak i inwestycje.

\section{Bibliografia}

Buchwald, A. (2009). Efektywność aktywnych programów rynku pracy $w$ Polsce ujęcie regionalne. Nieopublikowana praca doktorska, Uniwersytet Ekonomiczny w Poznaniu, Poznań. Pobrane 02.05.2017 z http://www.wbc.poznan.pl. 
Dolny, E., Wiśniewski, Z., i Wojdyło-Preisner, M. (2014). Długotrwałe bezrobocie w Polsce. W: Z. Wiśniewski, i M. Wojdyło-Preisner (red.), Diagnozowanie stopnia zagrożenia dtugotrwatym bezrobociem. Teoria i praktyka. Podręcznik do profilowania bezrobotnych na lokalnym rynku pracy. Warszawa: Ministerstwo Pracy i Polityki Społecznej i Centrum Rozwoju Zasobów Ludzkich.

Eurostat. (2017). Pobrane 02.05.2017 z http:// ec.europa.eu/eurostat.

GUS. (2017). Pobrane 02.05.2017 z Pobrane 02.05.2017 z http://stat.gov.pl.

Jaśkiewicz, M. (2016). Skutki bezrobocia dla jednostki i rodziny. Pobrane 02.05.2017 z http://www.rodon.radom.pl.

Kośko, M. i Osińska, M. (2007a). Estymacja jednorównaniowego liniowego modelu ekonometrycznego. W: M. Osińska (red.), Ekonometria Wspótczesna. Torun: TNOiK.

Kośko, M. i Osińska, M. (2007b). Specyfikacja modelu ekonometrycznego. W: M. Osińska (red.), Ekonometria Wspótczesna. Toruń: TNOiK.

MPiPS. (2014). Profilowanie pomocy dla osób bezrobotnych. Podręcznik dla pracowników powiatowych urzędów pracy. Pobrane 02.05.2017 z http://di.com.pl.
Ręklewski, M., i Ryczkowski, M. (2016). The Polish regional labour market welfare indicator and its links to other well-being measures. Comparative Economic Research, 19(3). doi:10.1515/ cer-2016-0023.

Ustawa $z$ dnia 20 kwietnia 2004 roku o promocji zatrudnienia i instytucjach rynku pracy (Dz.U. 2004 nr 99 poz. 1001).

Wiśniewski, Z. (2012). Aktywna polityka rynku pracy - wybrane zagadnienia. W: M. Maksim, i Z. Wiśniewski (red.), Metody i narzędzia badania efektywności aktywnej polityki rynku pracy. Warszawa: Centrum Rozwoju Zasobów Ludzkich.

Wojdyło-Preisner, M. (2009). Profilowanie bezrobotnych jako metoda przeciwdziatania długookresowemu bezrobociu. Toruń: Wydawnictwo Naukowe UMK.

Wojdyło-Preisner, M. (2013). Narzędzie do profilowania osób wymagających szczególnego wsparcia. W: Z. Wiśniewski, i M. Wojdyło-Preisner (red.), Profilowanie bezrobotnych wymagajacych szczególnego wsparcia na lokalnym rynku pracy. Toruń: Wydawnictwo Naukowe UMK.

\section{Informacje uzupełniające}

Wkład autorski: autor zaakceptował ostateczną wersję artykułu. 


\section{Aneks}

Tabela 1.

Wyniki estymacji modelu bezrobocia dla Polski

\begin{tabular}{cccc}
\hline Zmienna & Ocena parametru & Błąd standardowy & Wartość $p$ \\
\hline stała & 0,63 & 0,18 & 0,00 \\
$U_{t-1}$ & 0,94 & 0,00 & 0,00 \\
$P K B_{t-4}$ & $-0,08$ & 0,03 & 0,01 \\
$C P I_{t-2}$ & 0,16 & 0,03 & 0,00 \\
$E X_{t-1}$ & $-0,03$ & 0,01 & 0,00 \\
$I_{t-1}$ & $-0,06$ & 0,02 & 0,00 \\
$I_{t-3}$ & 0,04 & 0,02 & 0,05 \\
& & & $R^{2}=0,99$ \\
\end{tabular}

Żródło: Obliczenia własne.

Tabela 2.

Wyniki estymacji modelu bezrobocia dla Stanów Zjednoczonych

\begin{tabular}{cccc}
\hline Zmienna & Ocena parametru & Błąd standardowy & Wartość $p$ \\
\hline stała & $-0,41$ & 0,19 & 0,03 \\
$U_{t+1}$ & 1,04 & 0,20 & 0,00 \\
$P K B_{t-3}$ & 0,18 & 0,04 & 0,00 \\
$P K B_{t-4}$ & $-0,12$ & 0,03 & 0,00 \\
$C P I_{t}$ & 0,04 & 0,02 & 0,05 \\
$C P I_{t-3}$ & 0,05 & 0,01 & 0,00 \\
$E X_{t}$ & $-0,04$ & 0,01 & 0,00 \\
$E X_{t+1}$ & 0,03 & 0,01 & 0,00 \\
$I_{t-1}$ & $-0,02$ & 0,002 & 0,00 \\
$I_{t+2}$ & $-0,01$ & 0,002 & 0,00 \\
$I_{t-3}$ & $-0,01$ & 0,001 & - \\
& & & $R^{2}=0,99$ \\
\end{tabular}

Źródło: Obliczenia własne. 
Macroeconomic determinants of unemployment on the example of Poland and United States in years $2000-2016$

\section{Abstract}

Motivation: The motivation for choosing a subject was high importance of long-term unemployment for economic growth and methods of unemployed profiling to prevent that phenomenon.

Aim: The aim of the article was the selection of macroeconomic determinants of long-term unemployment in Poland and the United States. The analysis was also focused on discussing the possibility of combating long-term unemployment through the unemployed profiling and the current results of this method in Poland.

Results: The following macroeconomic variables had a statistically significant impact on the unemployment rate: the unemployment rate in the previous quarter, real GDP growth rate, inflation rate, growth rate for export share in GDP and investments. In most cases, this influence was in line with economic theory. In Poland, the unemployment rate is most responsive to changes in GDP in the opposite direction. It can be expected that stimulating economic growth or taking actions supporting it in the long run, should translate into a decrease in the unemployment rate in Poland. In the United States, growth rate for export share in GDP and investments had a significant impact on unemployment rate.

Keywords: unemployment; Poland; United States; unemployment determinants; unemployed profiling JEL: J64; E23; I3 